\title{
FORECAST OF OIL/GAS PROSPECTIVE SITES ON THE BASIS OF MODELS OF THE FAULT-BLOK TECTONICS OF THE NORTHERN PART OF THE CASPIAN REGIO
}

Лысин В.А., Пьянков В.Я.

\section{(ГНЦ ФГУГП «Южморгеология», Геленджик)}

On the basis of generalized materials of different-scale onshore and offshore gravimetric and magnitometric surveys and posterior spectral/frequency analisis of gravity and magnetic fields some variants of the fault-block tectonics of the northern part of the Caspian region have been developed. Main features of spatial connections between hidrocarbons fields and models of the fault-block tectonics have been revealed, and on the bases of the latter some oil/gas prospective sites have been picked out.

На основе обобщения материалов разномасштабных наземных и морских гравиметрических и магнитометрических съемок и последующего спектрально-частотного анализа гравитационного и магнитного полей разработаны варианты разломно-блоковой тектоники северной пасти Каспийского региона. Выяв.ены основные особенности пространственных связей месторождений углеводородов с моделями разломно-б.локовой тектоники, на основании которых намечены новые нефтегазоперспективные участки.

Спектрально-частотный анализ гравитационного и магнитного полей в совокупности с сейсмо-грави-магнитным моделировнием разрезов позвотяет оценивать оссбенности разломно-блоковой тектоники различных структурных этажей земной коры.

В рисунке распределения низкочастотных аномалий сильг гяжести Среднего, Северного Каспия и обрамляющей суши(период аноматий от 80 до 100 км), вызванных структурно-вещественными неоднородностями архейпротерозойских образований, выделяются дугообразные выпуклые к западу знакопеременные аномалии, пересеченные линейно-ориентированными в северо-западном направлении полосовыми аноматиями. В северном предгоръе мегантиклинория юго-восточного Кавказа и севернее на территории Прикумской зоны поднятий аномалии силы тяжести сгруппированы в виде кольцеобразных. Кольцеобразная форма аноматий намечается и в пределах Прикаспийской низменности, где в виде разорванного кольца группируются положительные аномалии Полдневского вата и суб̆меридиональные б.локи Джакуевского вала и Кобяковского поднятия.

Ко.њеобразные формы на территории Прикаспийской низменности наиболее отчетливо проявляются в распредетении низкочастотных аноматий силы тяжести периодичностью от 45 до $70 \mathrm{kм}$, обус.товленньх плотностной неоднородностью протерозойских образований. Первый участок кольцеобразньх аномалий расположен в северо-западной части рассматриваемой площади, где к внутреннему кольцу отрицательных аноматий силы тяжести приурочено Астраханское газоконденсатное месторождение. Второй участок кольцеобразных аноматнй расположен в северовосточной части площади. Здесь разрушенную кольцеобразную форму диаметром до 230 км имеют аномалии, которые с восточной стороны сопровождаются северными поднятиями Бузатинского свода, Приморской зоной поднятий и поднятиями Гурьевского свода, а с западной стороны поднятим Жамбай и поднятиями Новобогатинского свода На этом участке к внутреннему кольцу положитетьных аномалий силы тяжести приурочено поднятие Кашаган, в пределах которого выявлено одно из крупнейших месторождений углеводородов. На первом участке $\mathrm{x}$ внешнему кольцу положительных аномалий силы тяжести приурочены месторождения Цубукско-Промысловского вала. К градиентной зоне внутреннего кольца положительных аномалий силы тяжести приурочено месторождение углеводородов Джакуевского вала. Газовое месторождение восточной части Джакуевского вала приурочено к положительной аномалии силы тяжести в центратьной части кольцеобразньх аномалий. На втором участке к внешнему кольцу положительных аномалий силы тяжести приурочены нефтяные месторождения северной части Бузачинского свода, Приморской зоны поднятнй, Гурьевского свода,
Каработанского поднятия, Новобогатинского свода и поднятия Жамбай. К среднему кольцу положительных аномалий силы тяжести приурочены единичные нефтяные месторождения западньх частей Приморской зоны поднятий и Гурьевского свода и месторождение Тенгис, относящееся к крупнейшим. В южной части площади кольцеобразные аномалии силы тяжести оконтуривают с севера мегантиклинорий юго-восточного Кавказа и намечаются в виде деформированных, сптюснутых аномалий, расположенных южнее линейноориентированных аноматий Камышанско-Каспийского и Тюб-Караганского ватов. Месторождения нефти приурочены к внутреннему кольцу положительных аномалий силы тяжести мегантиксинория юго-восточного Кавказа, к линейным положительным аномалиям Тюб-Караганского вата и северовосточного замыкания Песчаномыского свода. Газовые и газоконденсатные месторождения приурочены к отришательным аномалиям силы тяжести Камышанско-Каспийского вала, Прикумской зоны поднятий, мегантиклинория юговосточного Кавказа и впадины между Беке-Башкудинского валом и Песчаномыским сводом.

Таким образом, в пределах Прикаспийской низменности крупнейшее газоконденсатное месторождение Астраханское и месторождение Кашаган расположены в центральных частях кольцевых структур низкочастотных аномалий силы тяжести. Раз.тичие зактючается в приуроченности Астраханского месторождения к кольцу отрицательных аномалий силы тяжести, а мсторождения Кашаган - к кольцу положительных аномалий силы тяжести. Месторождение Тенгис также расположено в кольцеобразной зоне низкочастотных положительных аномалий силы тяжести. Месторождение Жамбай приурочено к внешнему ко.тьцу низкочастотных отрицательных аноматий силы тяжести. Кольцеобразные аномалии силы тяжести (диаметр аномалий до 270км), сопровождающиеся ореолами поднятий и залежами углеводородов, на наш взг.ляд, несомненно указывает на флюидодинамическую проработку глубинных пластов земной коры.

Кроме отмеченных связей месторождений углеводородов с кольчевыми и линейно-ориентированными аномалиями силы тяжести, наглядно прослеживается приуроченность месторождений уг.теводородов к дугообразной зоной разломов восточного берега Каспийского моря, где подавляющее большинство нефтяных месторождений расположено вблизи узлов пересечений предполагаемой зоны раз.ломов с зонами положитетьных аномалий силы тяжести, линейно-ориентированными поперечно к Каспию. Месторождения углеводородов, открытые ООО «ЛУКОЙЛ» в средней части Каспийского моря, располагаются вблизи узлов пересечений регионатьной дугообразной зоны разломов средкнной части Каспийского моря с зонами линейно-ориентированных поперечных аномалий силы тяжести. Новое крупнейшее месторождение углеводородов им. В. Филановского приурочено к узлу пересечения срединной дугообразной зоны раломов вблизи ее перегиба с линейно ориентированной низкочастотной положительной аномалии силы тяжести, прослеживающейся с востока на продо.тжении Тюб-Караганского вала.

На основе выяв.ленных пространственньх связей месторождений углеводородов с вариантами разломноблоковой тектоники выделены участки наиболее перспективные на поиски новых месторождений уг.леводородов. 